HELMINTHOLOGIA, 57, 2: 129 - 144, 2020

\title{
The effect of soil type and ecosystems on the soil nematode and microbial communities
}

\author{
M. RENČO ${ }^{1 *}$, E. GÖMÖRYOVÁ ${ }^{2}$, A. ČEREVKOVÁ ${ }^{1}$ \\ IInstitute of Parasitology, Slovak Academy of Sciences, Hlinkova 3, 040 01, Košice, Slovak Republic, \\ E-mail: *renco@saske.sk, cerev@saske.sk; ${ }^{2}$ Faculty of Forestry, Technical University in Zvolen, TG Masaryka 24, \\ 960 53, Zvolen, Slovakia, E-mail: gomoryova@tuzvo.sk
}

Article info

Received July 11, 2019

Accepted February 21, 2020

\section{Summary}

Integrated studies are required to better understand the relationships between groups of soil microfauna under the influence of various biotic and abiotic factors that drive and characterise ecosystems. We analysed soil nematode communities and microbial diversity and the properties of three soil types to assess the effect of these environmental variables on biological diversity in natural (forest), semi-natural (meadow), and managed (agriculture) habitats of the Slovak Republic. The type of ecosystem and soil and the interaction of both factors had considerable effects on most monitored abiotic and biotic soil properties. The forest with a Chernozem soil had the most nematode species, highest nematode diversity, highest abundance of nematode within functional guilds, best values of ecological and functional indices, highest microbial biomass, highest microbial richness and diversity, and the highest values of various soil properties, followed by meadows with a Cambisol soil. The agricultural ecosystem with a Stagnosol soil had the lowest biological diversity and values of the soil properties. Several nematode species were new for Slovak nematode fauna. Sampling date and the interaction of all three factors (ecosystem $\times$ soil $\times$ date) had minor or no effect on most of the parameters, except soil moisture content, microbial richness, nematode channel ratio, nematode maturity index, and plant parasitic index. Both the biological indicators and basic soil properties indicated that the natural forest with a Chernozem soil was the best habitat from an ecological point of view. This ecosystem is thus the most appropriate for ecological studies.

Keywords: soil trophic web; indicators; soil properties; nematodes; microbes; multivariate analysis

\section{Introduction}

Soil is an extremely heterogeneous environment in all aspects: biological, physical, chemical, and structural. Biological diversity is substantially higher in soil than above it, numbers are much larger for populations of soil organisms than aboveground communities (Young \& Ritz, 1998). Microbes (fungi, bacteria, and algae), microfauna (protozoa), and mesofauna (arthropods and nematodes) belong to the most diverse soil organisms (Neher, 2001), affected mainly by vegetation and edaphic factors (Nielsen et al., 2014). Nematodes inhabit nearly every environment and as biotic indicators are one of the most studied groups of soil organisms (Bhusal et al., 2014). Since nematodes have diverse feeding behaviour and life strategies and play a key role in soil food web, they function as important indicator for ecosystems processes (Ferris 2010). As nematodes show different degrees of sensitivity to the environmental stimuli, alterations or disturbances because they have different long life cycles and reproduction capacity (Bongers, 1990),

\footnotetext{
* - corresponding author
} 
species diversity and structure of community what is important indicator of soil health and conditions (Neher, 2001). In addition, nematode indices allow the evaluation of ecosystem nutrient status (enriched vs. depleted), structure of soil food web (complexity vs. simplicity) and the prevailing decomposition of organic matter (slower fungal vs. faster bacterial) (Ferris et al., 2001).

In contrast to nematode community's structure, however, potential microbial community structure for use as indicators of soil quality and functioning are hampered by a lack of standardised assays of microbial ecological diversity (Schutter et al., 2001). Culturing techniques have been used to identify the number of specific taxonomic or functional groups, but only a small fraction of a microbial community $(1-10 \%)$ can be identified with these methods (Olembo \& Hawksworth, 1991; Nannipieri et al., 2003). Analyses of microbial DNA (Martin-Laurent et al., 2001, Zhang et al., 2014) can identify taxonomic groups at different levels, but developing specific primers, for example, is problematic. PLFA analyses cannot identify organisms to the species level but can be used to estimate gross changes in community structure (Kaur et al., 2005). BIOLOG $^{\circledR}$ EcoPlates are now commonly used for measuring microbial functional diversity based on the use of sources of available carbon (C) (Garland \& Mills, 1991), and the method proposed by Degens and Harris (1997) for measuring the catabolic potential of microbial communities is often used in measurements of the impacts of soil management due to the easy use of both methods. Nevertheless, several microbial and biochemical attributes such as respiration, $\mathrm{N}$ mineralisation, or enzymatic activities can be reliably measured and are also frequently used as indicators of soil quality (Blagodatskii et al., 2008; Gömöryová et al., 2013, Bobul'ská et al., 2015, Zhang et al., 2014).

Worldwide, several particular studies have revealed that environmental conditions determines the degree of species diversity of soil nematodes or nematode abundance e.g. ecosystem type and its properties (Neher et al., 2005; Nielsen et al., 2014), soil type and its properties (Lišková et al., 2008, Hu et al., 2018; Lima da Silva et al., 2019); vegetation and its species diversity (Cesarz et al., 2013; Renčo \& Baležentiené, 2015). Similar, microbial activity and biomass have been evaluated in arable soils due to crop production as affected by tillage (Mangalassery et al, 2015); fertilizers (Kautz et al., 2004; Zakarauskaitè, et al., 2008) or management system (Bloem et al., 1992); in forest soil as affected by forest type (Fang et al., 2016) or in grasslands affected by plant diversity (Lange et al., 2015). The structure of soil nematode communities and microbial diversity, however, have not been investigated or compared amongst various land use (ecosystems) and main soil types in the territory of Slovak Republic in collaborative study. We studied the soil properties and nematode-microbial assemblages in three soil types and three ecosystems to evaluate 1) nematode and microbial diversity in ecosystems with different soil types, 2) the fundamental variability in soil properties amongst and within the ecosystems and soil types, and 3 ) the effects of soil properties and sampling date on the nematodes and microbes in the eco- systems and soil types. We hypothesised that biological diversity would be lower in agroecosystems, that soil trophic webs would be more coherent in natural habitats, but that the differences between ecosystems would vary with the physicochemical properties of the soil type.

\section{Materials and Methods}

\section{Site selection}

We examined the physical and chemical properties, nematode communities, and microbial attributes in soil samples collected from a Stagnosol (SS), a Cambisol (CS), and a Chernozem (CM) in each of a forest (FOR), a meadow (MEA), and an agricultural field (AGR) ecosystems. The soil types, ecosystems, locations, and vegetation characteristics are shown in Table 1.

\section{Soil samples and properties}

Soil samples from each soil type and ecosystem were collected from five randomly established $1 \times 1 \mathrm{~m}$ quadrats in selected plots of $20 \times 20 \mathrm{~m}$ in May (M), July (J), and September (S) 2016. Five randomised subsamples were collected from the quadrats, one from each corner and one from the centre of the plots, for analysing the soil nematode communities, microbial activities, and physicochemical properties. The subsamples were bulked to produce a representative sample for the plot $(1 \mathrm{~kg})$. Samples were collected from a depth of $10 \mathrm{~cm}$, excluding the surface humus layer. A total of 135 representative samples were collected; 5 from each ecosystem (FOR, MEA, and AGR, 5×3=15), from three soil type (SS, CS, and CM; 15×3=45), in three sampling date (M, J, and $S ; 45 \times 3=135)$. The samples were transferred to the laboratory in sealed plastic bags and stored at $5{ }^{\circ} \mathrm{C}$ until processing for the nematode analysis or at $-20^{\circ} \mathrm{C}$ for the microbial analysis.

Total soil $\mathrm{C}$ and nitrogen ( $\mathrm{N}$ ) contents, soil moisture (SM) contents, and $\mathrm{pH}$ were measured in all samples. The organic $\mathrm{C}$ and total $\mathrm{N}$ contents were determined using a Vario MACRO Elemental Analyzer (CNS Version; Elementar, Hanau, Germany). Organic C content was determined based on the difference between total $C$ and $\mathrm{C}$ bound in carbonates. SM content was estimated gravimetrically by oven-drying fresh soil at $105^{\circ} \mathrm{C}$ overnight, and $\mathrm{pH}$ was measured potentiometrically in $1 \mathrm{M} \mathrm{KCl}$ suspension by a digital $\mathrm{pH}$ meter separately for each representative sample.

\section{Analysis of nematode communities}

Each sample was homogenised by gentle hand mixing, and stones were manually removed. The nematodes were extracted from $100 \mathrm{~g}$ of fresh soil by a combination of Cobb sieving and decanting (Cobb 1918) and a modified Baermann technique (van Benzoijen, 2006). One hundred grams of soil from each representative sample were soaked in I L of tap water for 60 min to disrupt soil aggregates and promote nematode movement. The soaked sample was carefully passed through a 1-mm sieve (16 mesh) to remove plant parts and debris, and this suspension was passed 
Table 1. Soil type, location, ecosystem type, and vegetation characteristics of the study plots.

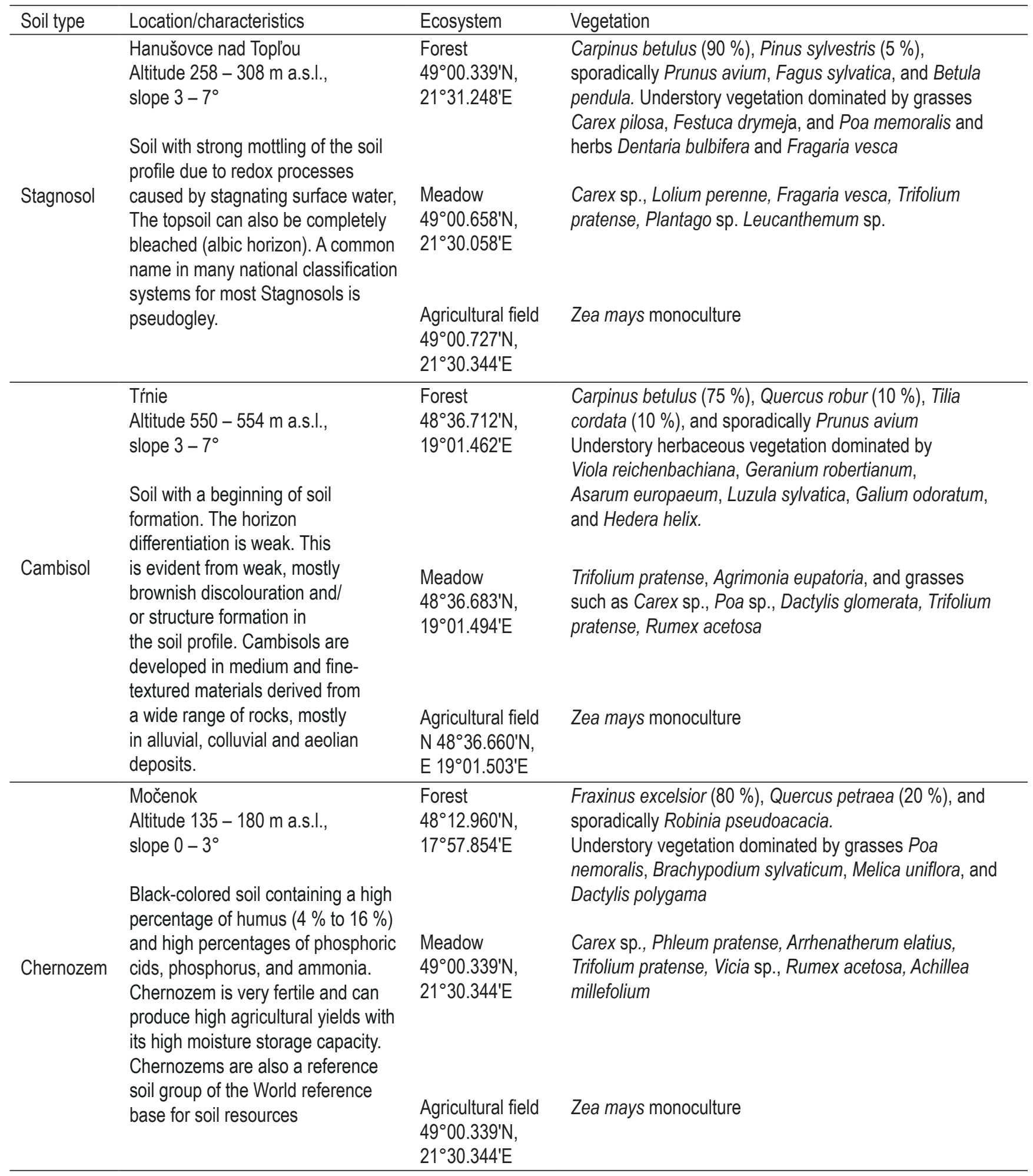


through a 50- $\mu$ m sieve (300 mesh) 2 min later to remove water and very fine soil particles. The nematodes were then extracted from the soil/water suspension by a set of two cotton-propylene filters in the Baermann funnels. Two filter trays were used per sample to limit material thickness to $<0.5 \mathrm{~cm}$. Suspensions containing the nematodes were collected after extraction for $24 \mathrm{~h}$ at room temperature. The nematodes were killed and fixed in a hot 99:1 solution of $4 \%$ formaldehyde and pure glycerol (Seinhorst, 1962). The all nematodes were microscopically $(100,200,400,600$, and $1000 \times$ magnification) identified to the species level (juveniles to the genus level) from temporary slides using an Eclipse 90i light microscope (Nikon Instruments Europe BV, Netherlands). Nematode abundance was expressed as the number of individuals per $100 \mathrm{~g}$ of dry soil.

The nematodes were assigned to fifteen functional guilds integrating nematode feeding strategies (trophic groups) and the nematode coloniser-persister (c-p) scale (Bongers \& Bongers, 1998). The five nematode trophic groups were: bacterivores $(\mathrm{Ba})$, fungivores $(\mathrm{Fu})$, carnivores $(\mathrm{Ca})$, omnivores $(\mathrm{Om})$, and plant parasites (Pp) (Wasilewska, 1997). The Pp group included both obligatory plant parasites and facultative plant parasites that may attack plants or fungi. Colonisers-persisters characterising nematode life strategies are classified on a scale of 1 to 5 (Bongers, 1990). C-p1 represents "r-strategists" (colonisers) with short life cycles, small eggs, high fecundity, high colonisation ability, and high tolerance to disturbance, eutrophication, and anoxybiosis. Colonisers generally live in ephemeral habitats. At the other end of the scale, c-p5 nematodes represent "k-strategists" (persisters) with the longest generation times, largest bodies, lowest fecundities, and the highest sensitivity to disturbance. Persisters are never dominant in a sample and generally live in stable habitats where they become very abundant (Bongers, 1990). C-p scaling allows the calculation of the basal maturity index (MI) for non-parasitic nematodes, the plant parasitic index (PPI) for plant parasites only (Bongers, 1990),

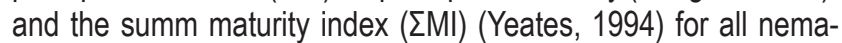
tode taxa. Functional guilds allow the calculation of the enrichment index (EI), the structure index (SI), and the channel index $(\mathrm{CI})$ proposed by Ferris et al., (2001). The species-diversity index $\left(\mathrm{H}^{\prime}\right)$ defined by Shannon and Weaver (1949), the nematode channel ratio (NCR) defined by Yeates (2003), and trophic diversity (TD) defined by Heip et al., (1998) were also calculated.

Nematode species were characterised as dominant at D $>5 \%$ (the species represents more than $5 \%$ of the total nematode abundance in the ecosystem or soil type) and subdominant at D $>2 \%$ (the species represents more than $2 \%$ of the total nematode abundance in the ecosystem or soil type) (Losos et al., 1984).

\section{Microbial biomass}

Microbial biomass C (Cmic) content was determined following the procedure described by Islam and Weil (1998). Ten grams of oven-dried equivalent (ODE) of field moist soil adjusted to $80 \%$ water-filled porosity was irradiated twice by microwaves (MW) at
$400 \mathrm{~J} \mathrm{~g}^{-1}$ ODE soil to kill the microorganisms. The cooled samples were extracted with $0.5 \mathrm{M} \mathrm{K}_{2} \mathrm{SO}_{4}$, and the $\mathrm{C}$ content of the extract was quantified by oxidation with $\mathrm{K}_{2} \mathrm{Cr}_{2} \mathrm{O}_{7} / \mathrm{H}_{2} \mathrm{SO}_{4}$. The same procedure was performed with a non-irradiated sample. Cmic content was determined as (Cirradiated content - Cnon-irradiated content)/ $\mathrm{KME}$, where KME represents the extraction efficiency $(0.213)$ recommended by Islam and Weil (1998).

\section{Functional diversity of microbial communities}

The functional diversity of the soil microbiota was determined using the methods described by Insam (1997). Each well in a BIOLOG EcoPlate received $150 \mu$ of an extract prepared by resuspending of fresh soil in $0.85 \% \mathrm{NaCl}$ and diluted 1:10000. The plates with the extracts were then incubated at $27{ }^{\circ} \mathrm{C}$ for $6 \mathrm{~d}$, and absorbance at $590 \mathrm{~nm}$ was recorded every $24 \mathrm{~h}$ using a Sunrise Microplate reader (Tecan, Salzburg, Austria). The data were corrected against the initial readings at time zero and were expressed as optical densities of individual wells. The richness of the soil microbial community (Richn) was determined as the number of substrates used by the microbial community, i.e. the number of wells with a positive response after background correction. Hill's diversity index (Diver) (Hill, 1973) based on Eq. 1 was calculated for estimating the diversities of the microbial functional groups:

$$
\text { Diver }=1 / \sum p_{i}^{2}
$$

in which $p_{i}$ is the ratio of the activity on a substrate to the sum of activities on all substrates.

\section{Data analysis}

Data were log-transformed before analysis to improve normality. Soil and ecosystem types were included as fixed factors. The effects of soil type (SS, CS, and CM), type of ecosystem (FOR, $M E A$, and $A G R)$, and sampling date (M, J, and S) on nematode trophic-web descriptors and functional guilds, soil properties, and microbial biomass, diversity, and richness were analysed by factorial analyses of variance (ANOVAs). Nonparametric Spearman's correlation coefficient (rs) was calculated to test the relationships between nematode functional guilds, microbial parameters, and soil parameters for each sample using STATISTICA v9.0. Correlations obtained at $P<0.05$ were considered significant.

We then used multivariate analyses to evaluate the effects of soil and ecosystem types on nematode-community composition and the microbial characteristics. The composition of the nematode functional guilds and the microbial parameters were thus used as response variables, and the soil and ecosystem types were used as explanatory variables in a multivariate framework of a redundancy analysis (RDA). The soil physicochemical parameters were used as supplementary variables. Canoco 5 for Windows was used for the multivariate analyses (vers. 5.04; Ter Braak \& Šmilauer, 2012). 


\section{Ethical Approval and/or Informed Consent}

This article does not contain any studies with human participants or animals by any of the authors, so formal consent is not required. Authors have no potential conflict of interest pertaining to this submission to Helminthologia.

\section{Results}

\section{Soil properties}

The factorial ANOVA found that ecosystem type (FOR, MEA, and AGR) and soil type (SS, CS, and CM) significantly affected all soil properties (except SM content vs. soil type) and that sampling date $(\mathrm{M}, \mathrm{J}$, and $\mathrm{S})$ affected only SM content $(P<0.01$, Table 2$)$. The bi-factorial interaction ecosystem $\times$ soil significantly affected all soil properties, ecosystem $\times$ date affected half of the properties, and soil $x$ date and the interaction of all three factors (ecosystem $x$ soil $x$ date) had minor or no effects on the soil properties. The values of the soil properties were generally higher in the FOR soils (except pH) than the MEA and AGR soils and higher in CM (including $\mathrm{pH}$ ) than $\mathrm{CS}$ and $\mathrm{SS}$. $\mathrm{pH}$ and the $\mathrm{C} / \mathrm{N}$ ratio were correlated negatively in FOR but positively in AGR and MEA (Fig. 1).

Nematode and microbial trophic webs

The three ecosystems and soil types contained 133 nematode species (32 bacterivores, 26 fungivores, 9 carnivores, 24 om-
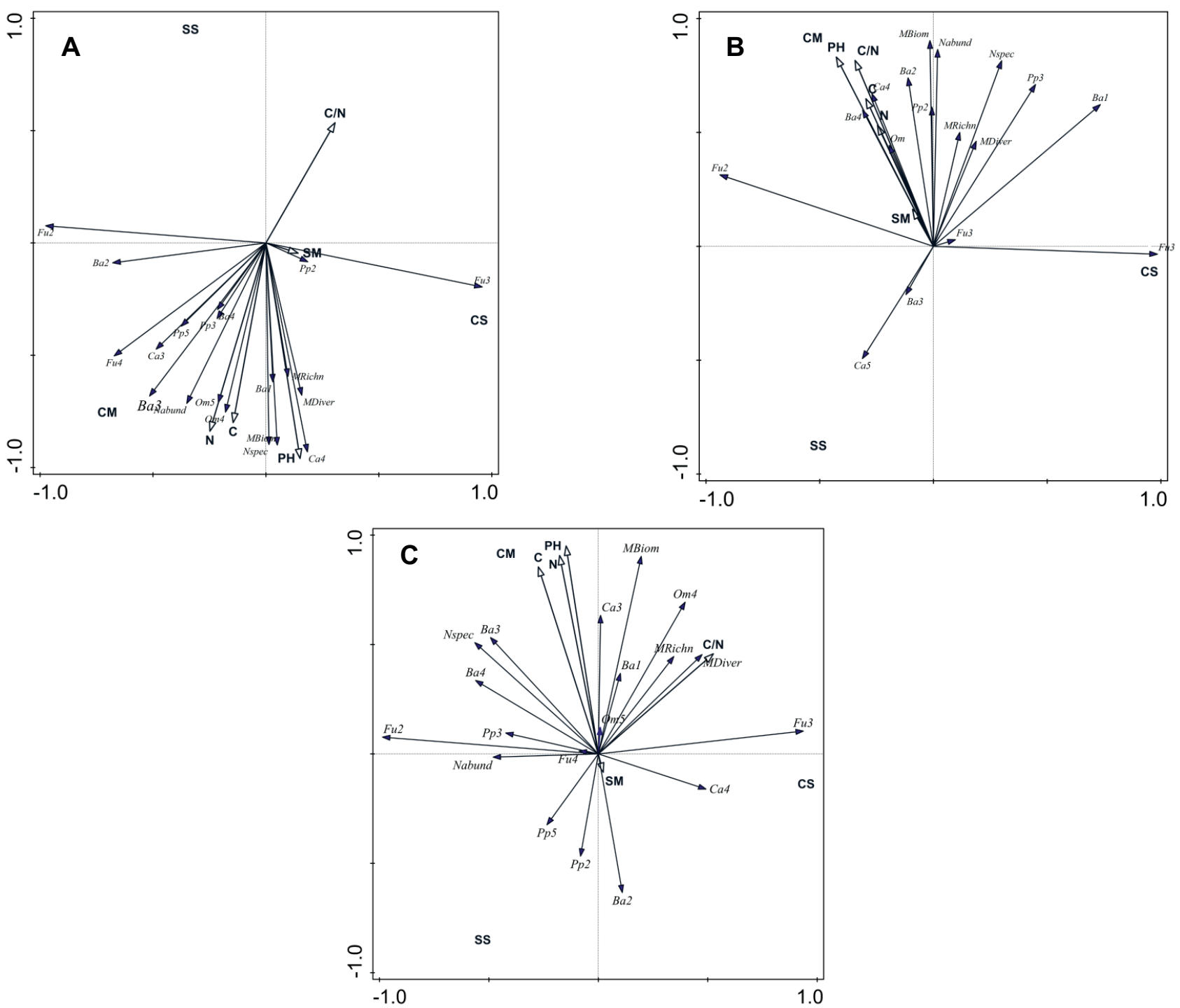

Fig. 1. RDA triplots of the relationships of abundance of nematode functional guilds, microbial parameters, and soil properties in the forest (A), agricultural field (B), and meadow (C) ecosystems and the Stagnosol (SS), Cambisol (CC), and Chernozem (CM) soil types. 


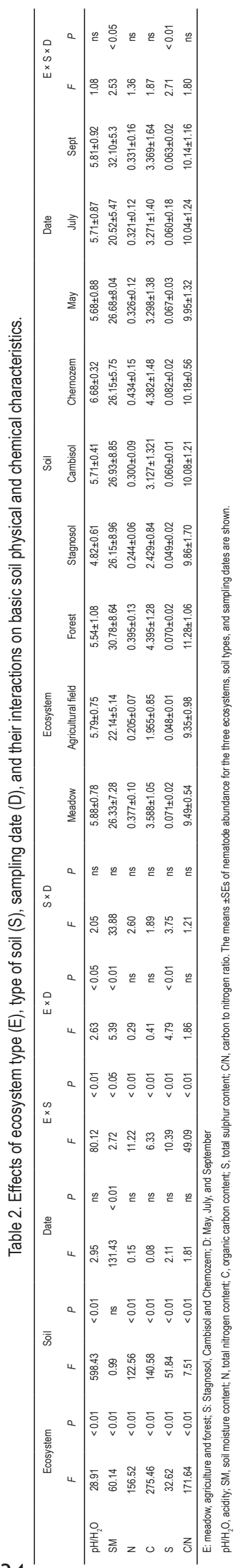

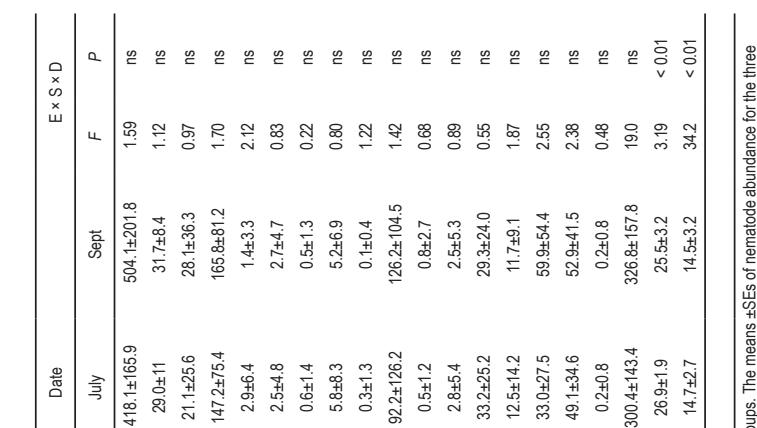

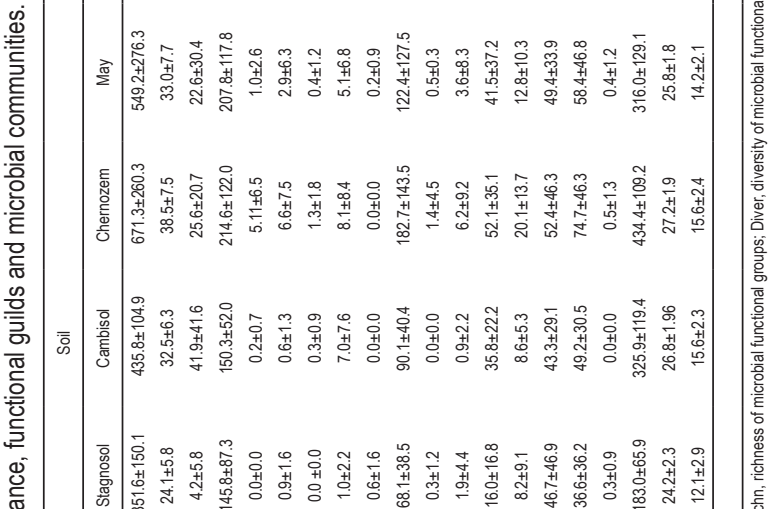

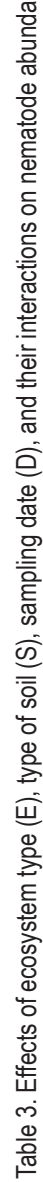

,

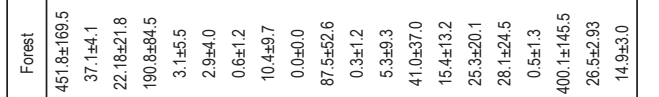

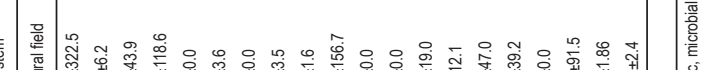

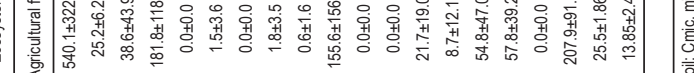

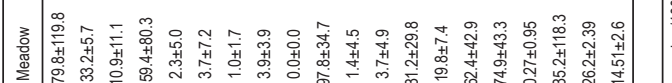

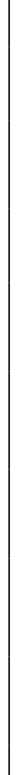

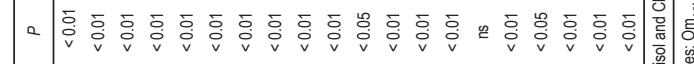

高

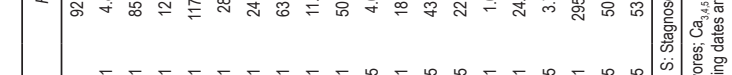

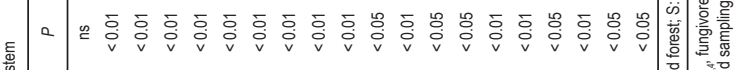

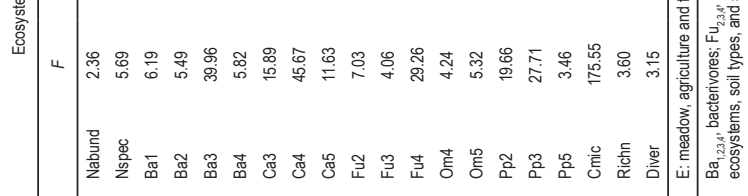

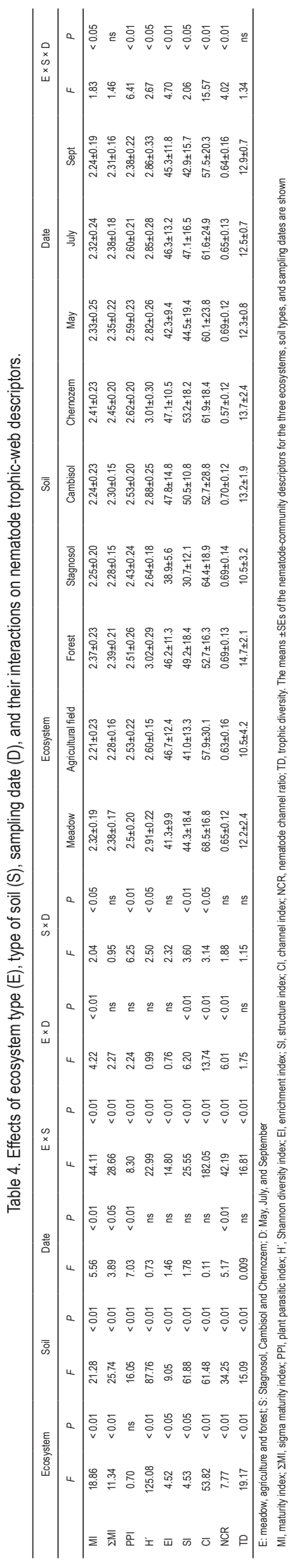


Table 5. Spearman's rank correlation coefficients between nematode abundance, species number, functional guild, microbial parameters and soil properties.

\begin{tabular}{|c|c|c|c|c|c|c|}
\hline & $\mathrm{pH} / \mathrm{H}_{2} \mathrm{O}$ & SM & $\mathrm{N}$ & C & $S$ & $\mathrm{C} / \mathrm{N}$ \\
\hline Nabund & $0.35^{* *}$ & $0.68^{* * *}$ & $0.42^{* * *}$ & $0.29^{* *}$ & ns & ns \\
\hline Nspec & $0.22^{*}$ & ns & $0.31^{*}$ & $0.37^{\star * *}$ & ns & ns \\
\hline $\mathrm{Ba}_{1}$ & $0.44^{* *}$ & ns & $0.25^{\star * *}$ & $0.22^{*}$ & $0.31^{* * *}$ & ns \\
\hline $\mathrm{Ba}_{2}$ & ns & $-0.23^{\star * *}$ & ns & $\mathrm{ns}$ & ns & ns \\
\hline $\mathrm{Ba}_{3}$ & $0.54^{* * *}$ & $0.26^{*}$ & $0.44^{* * *}$ & $0.41^{* * *}$ & $0.42^{* * *}$ & $0.21^{*}$ \\
\hline $\mathrm{Ba}_{4}$ & $0.43^{* * *}$ & ns & $0.30^{* * *}$ & $0.29^{* \star *}$ & $0.30^{* * *}$ & ns \\
\hline $\mathrm{Ca}_{3}$ & $0.44^{\star * *}$ & $0.46^{* * *}$ & $0.39 * * *$ & $0.40^{* * *}$ & $0.39^{* * *}$ & $0.33^{* * *}$ \\
\hline $\mathrm{Ca}_{4}$ & $0.41^{* * *}$ & ns & $0.21^{*}$ & $0.22^{*}$ & $0.22^{* *}$ & $0.21^{* *}$ \\
\hline $\mathrm{Ca}_{5}$ & ns & $0.41^{* * *}$ & $0.35^{*}$ & $\mathrm{~ns}$ & $0.36^{*}$ & $0.26^{*}$ \\
\hline $\mathrm{Fu}_{2}$ & $0.55^{\star \star *}$ & ns & $0.35^{\star * *}$ & $0.29^{* *}$ & $0.37^{* * *}$ & ns \\
\hline $\mathrm{Fu}_{3}$ & ns & ns & ns & ns & ns & ns \\
\hline $\mathrm{Fu}_{4}$ & $0.39^{* * *}$ & $0.37^{* * *}$ & $0.29^{* * *}$ & $0.26^{* *}$ & $0.27^{* *}$ & ns \\
\hline $\mathrm{Om}_{4}$ & $0.42^{* * *}$ & ns & $\mathrm{ns}$ & $\mathrm{ns}$ & $0.33^{* *}$ & ns \\
\hline $\mathrm{Om}_{5}$ & $0.38^{* * *}$ & ns & $0.21^{*}$ & ns & $0.23^{* *}$ & ns \\
\hline $\mathrm{Pp}_{2}$ & ns & ns & ns & ns & ns & $-0.27^{* \star *}$ \\
\hline $\mathrm{Pp}_{3}$ & $0.47^{* * *}$ & $0.24^{* * *}$ & ns & ns & $\mathrm{ns}$ & ns \\
\hline $\mathrm{Pp}_{5}$ & $0.39^{* * *}$ & $0.37^{* * *}$ & $0.28^{* * *}$ & $0.28^{* * *}$ & $0.29^{* *}$ & $0.38^{* * *}$ \\
\hline Cmic & $0.70^{* * *}$ & $0.39^{* * *}$ & $0.90^{* * *}$ & $0.91^{* * *}$ & $0.83^{* * *}$ & $0.51^{* * *}$ \\
\hline Richn & $0.46^{\star \star *}$ & ns & $0.47^{* * *}$ & $0.45^{\star \star *}$ & $0.53^{* * *}$ & ns \\
\hline Diver & $0.47^{\star * \star}$ & ns & $0.40^{* * *}$ & $0.38^{* \star *}$ & $0.50^{\star * *}$ & ns \\
\hline
\end{tabular}

${ }^{*}, P<0.05 ;{ }^{* *}, P<0.01 ;{ }^{* * *}, P<0.001 ;$ ns, not significant

$\mathrm{Ba}_{1,2,3,4}$, bacteriovores; $\mathrm{Fu}_{23,4}$, fungivores; $\mathrm{Ca}_{3,4,5}$, carnivores; $\mathrm{Om}_{4,5}$, omnivores; $\mathrm{Pp}_{2,3,5}$, plant parasites; $\mathrm{Cmic}$, microbial biomass carbon content; Richn, richness of microbial functional groups; Diver, diversity of microbial functional groups; $\mathrm{pH} / \mathrm{H}_{2} \mathrm{O}$, acidity; $\mathrm{SM}$, soil moisture content; $\mathrm{N}$, total nitrogen content; $\mathrm{C}$, organic carbon content; $\mathrm{S}$, total sulphur content; $\mathrm{C} / \mathrm{N}$, carbon to nitrogen ratio

nivores, and 42 plant parasites) (Table S1). Heterocephalobus eurystoma, Stegetellina leopolitensis, Ditylenchus parvus, Ditylenchus tenuides, Paraphelenchus obscurus, Boleodorus volutus, Cephalenchus intermedius, and Ecphyadophora tenusissima were new to the list of Slovak nematode fauna, increasing the total number of soil nematode species to 732 . The number of species (99) and diversity were highest in the FOR soils, followed by the MEA (90) and AGR (53) soils. Nematode species number and diversity were higher in CM than CS and SS $(102,81$, and 60 , respectively) (Tables S1, 4). The most abundant nematode species by trophic group were Acrobeloides nanus and Chiloplacus propinquus (bacterivores), Aphelenchus avenae and Filenchus vulgaris (fungivores), Clarkus papillatus and Mylonchulus brachyuris (carnivores), Eudorylaimus carteri (omnivores), and Aglenchus agricola, Boleodorus thylactus, and Bitylenchus dubius (facultative and obligate plant parasites) (Table S1).

Soil type and sampling date had significant effects on overall nematode abundance $(P<0.01)$, but ecosystem type did not (Table 3 ). Ecosystem and soil types significantly influenced the abundances of all nematode functional guilds (except $\mathrm{Om}_{5}$ and $\mathrm{Pp}_{2}$, respectively), but the nematode-community compositions were similar.
The mean abundance of $\mathrm{Ba}_{2}$ nematodes was significantly higher in FOR than MEA and AGR $(P<0.01)$ and in $C M$ than $S S$ and $C S$ $(P<0.01)$. The amount of microbial biomass and microbial richness and diversity had tendencies similar to those of the $\mathrm{Ba}_{2}$ nematodes; all were higher in FOR and CM (Table 3). $\mathrm{Ba}_{4}, \mathrm{Fu}_{3}$, and $\mathrm{Pp}_{2,3}$ nematodes were most abundant in $\mathrm{MEA}, \mathrm{Ba}_{1}$ and $\mathrm{Fu}_{2}$ were most abundant in $\mathrm{AGR}$, and $\mathrm{Ba}_{3}, \mathrm{Ca}_{3,4}, \mathrm{Fu}_{4}, \mathrm{Om}_{4,5}$, and $\mathrm{Pp}_{5}$ were most abundant in FOR. The majority of the nematode functional guilds were more abundant in CM than SS and CS. Only Ba was significantly more abundant in CS $(P<0.01)$. Sampling date only significantly affected the abundance of c-p2 nematode (Ba, $\mathrm{Fu}$, and $\mathrm{Pp}$ ) trophic groups, with higher values in $\mathrm{M}$ and $\mathrm{S}$ than $\mathrm{J}$. Microbial richness was also affected by sampling date and was highest in $\mathrm{J}(P<0.01)$.

Nematode abundance, species number, and functional guilds and the microbial parameters were positively correlated with all soil properties. Only the $\mathrm{Ba}_{2}$ nematode parameters were negatively correlated with $\mathrm{SM}$ content, and the $\mathrm{Pp}_{2}$ nematode parameters were negatively correlated with the $\mathrm{C} / \mathrm{N}$ ratio (Table 5). The RDA analysis, however, indicated that the abundance of most of the nematode guilds, total nematode abundance, nematode species 
number, and the microbial parameters tended to be higher in environments with higher $\mathrm{pHs}$ and that $\mathrm{N}$ and $\mathrm{C}$ contents tended to be higher in FOR and CM soil (Figure 1A), except for $\mathrm{Fu}_{2}$ and $\mathrm{Fu}_{3}$ nematodes. The presence and distribution of nematodes within functional guilds, number of species, nematode abundance, and the microbial parameters in MEA were more affected by soil type than soil properties.

\section{Nematode trophic-web descriptors}

The ANOVA found that ecosystem and soil types significantly affected all descriptors (except PP vs. ecosystem type). Sampling date had a significant effect on Ml, $\Sigma \mathrm{Ml}, \mathrm{PPI}$, and NCR $(P<0.01$, 0.05 , Table 4). The interaction ecosystem $\times$ soil significantly affected all descriptors $(P<0.01)$, ecosystem $\times$ date and soil $\times$ date significantly affected half of the descriptors, and the interaction of all three factors (ecosystem $\times$ soil $\times$ date) affected the majority of the descriptors. MI, $\Sigma \mathrm{MI}, \mathrm{PPI}, \mathrm{H}^{\prime}, \mathrm{SI}$, and TD were generally higher in FOR than MEA and AGR soils and in CM than CS and SS. EI was highest in AGR and CS, $\mathrm{Cl}$ was highest in MEA and SS, and NCR was highest in FOR and CS.

\section{Discussion}

Nematode and microbial communities have been evaluated for their ability to detect changes in response to environmental impacts (e.g. wildfire, windstorms, and plant invasion) or human activities (e.g. pollution, land management, and ecosystem conversions) in many studies (Schutter et al., 2001; Gömöryová et al., 2011; Jangid et al., 2011; Whitford et al., 2014; Čerevková et al., 2013; Renčo et al., 2015; Renčo \& Baležentiené, 2015; Sánchez-Moreno et al., 2018). In present comprehensive study we evaluated their differences amongst ecosystems (natural, semi-natural, and managed) and soil types (CM, CS, and SS) measured by various community parameters. Such works where nematodes and microbes are surveyed together are rare (Ekschmitt et al., 2001; Briar et al., 2007). We also analysed the basal soil physicochemical properties and interactions with both nematode and microbial communities.

Relationships of ecosystem type with soil properties and nematode and microbial communities

Ecosystem type was an important factor shaping soil nematode and microbial communities and affecting soil properties. The abiotic and biotic soil properties and interactions amongst them were best for the FOR ecosystem. FOR had the highest SM, C, and $\mathrm{N}$ contents and $\mathrm{C} / \mathrm{N}$ ratio but the lowest $\mathrm{pH}$. $\mathrm{C}$ and $\mathrm{N}$ contents were twice as high in FOR than AGR but were similar to those in MEA. The supposed benefits of management of agricultural land (e.g. tillage, fertilisation, and crop rotation) include increased soil $\mathrm{C}$ and $\mathrm{N}$ contents, fertility, water retention, and overall provision of ecosystem services (Garbach et al., 2017; Sánchez-Moreno et al., 2018). The low $C$ and $N$ contents in our AGR soils, however, suggested differences in the quantity and quality of inputs to the soil, nutrient inputs and losses, low plant diversity and stimulation of decomposition by soil disturbance compared to the semi-natural (MEA) and natural (FOR) ecosystems. These results are in agreement with many studies of differences in soil $\mathrm{C}$ and $\mathrm{N}$ contents and changes following conversion of forest to managed agricultural land, well summarised in a review by Murty et al., (2002). This review revealed that large amounts of $C$ and $N$ could be lost when forest is converted into cultivated land but that no changes in soil $\mathrm{C}$ and $\mathrm{N}$ contents were recorded when forests were converted to uncultivated pasture (similar to our meadow). In contrast, the abandonment and reforestation of agricultural land can substantially increase $\mathrm{C}$ and $\mathrm{N}$ storage (Compton and Boone 2000), due to increase in plant diversity (Lange et al., 2015). Additionally, cultivated soils usually have lower $\mathrm{C} / \mathrm{N}$ ratios than forest soils (Murty et al., 2002), consistent with our and other results (Fernandes et al., 1997; Smil, 1999; Compton \& Boone, 2000). Our C/N ratio was negatively correlated with $\mathrm{pH}$ in $\mathrm{FOR}$, consistent with the results reported by Högberg et al., (2007).

Food, water, and temperature are the three primary factors that determine the habitats occupied by nematodes and microbes, the degree of species diversity, and the composition and structure of their communities. The availability of food, water, and temperature, however, are determined by ecosystem type, soil characteristics (e.g. structure, $\mathrm{pH}$, and chemistry), plant composition, and microclimatic (Neher, 2010) or seasonal (Gaugler \& Bilgrami, 2004) variations. More diverse nematode and microbial assemblages contribute to more resilient ecosystem services (Yeates, 2007; Fuhrman, 2009; Háněl, 2017). Forest soils, for example, contain more species than agricultural soils (Domsch et al., 1983; Neher et al., 2005), some with $>400$ nematode species (Yeates, 2007). This finding is consistent with our results; nematode species numbers and diversity $\left(\mathrm{H}^{\prime}\right)$ were highest for FOR, even though FOR had the lowest overall nematode abundance, suggesting that established forests represent relatively stable environments providing suitable conditions for maintaining balanced and rich nematode trophic webs (Yeates, 2007). This was supported also by values of ecological and functional indices (Bongers, 1990; Ferris et al., 2001). All maturity indices (MI, $\Sigma \mathrm{MI}, \mathrm{PPI})$ as well as Structure index and Trophic diversity were generally higher in forests than in grasslands and/or cultivated soils. These results partially agree with those by Neher et al., (2005), who reported that MI, PPI and SI were higher in forests than in wetlands and agricultural soils. Ecosystem type has significant effect on values of $\mathrm{Cl}$, which was the highest in meadow soils in our study, indicates a higher proportion of fungal decomposition (fungal decomposition channels) and low abundance of c-p1 bacterial feeders (e.g. Rhabditidae and Panagrolaimidae) (Ferris et al., 2001). In contrast, Neher et al., (2005) revealed the highest $\mathrm{Cl}$ value in forest soils.

We found several nematode species exclusively in one ecosystem e.g. Paraphelenchus obscurus in AGR, Paratylenchus microdorus in MEA, and Filenchus polyhypnus in FOR. Extreme disturbanc- 
Table S1. Mean abundance of nematode species (100 $\mathrm{g}$ of dry soil) in the three ecosystems (forest (FOR), meadow (MEA), and agricultural field (AGR)) and types of soil (Stagnosol (SS), Cambisol (CS), and Chernozem (CM)) $(n=45)$. Bold figures indicate dominance $>2$ but $<5 \%$, and bold and underlined figures indicate dominance $>5 \%$.

\begin{tabular}{|c|c|c|c|c|c|c|c|}
\hline & & \multicolumn{3}{|c|}{ Ecosystem } & \multicolumn{3}{|c|}{ Soil } \\
\hline Taxon & TG/FG & FOR & MEA & AGR & SS & CS & $\mathrm{CM}$ \\
\hline Mesorhabditis spp. juvs & $\mathrm{Ba1}$ & 13.5 & 0.6 & 13.4 & & 17.4 & 10.1 \\
\hline Panagrolaimus rigidus & Ba1 & 2.0 & 6.1 & 7.2 & 1.3 & 5.8 & 8.2 \\
\hline Rhabditis spp. juvs & $\mathrm{Ba} 1$ & 6.7 & 4.3 & 18.1 & 2.9 & 18.7 & 7.4 \\
\hline Acrobeles ciliatus & $\mathrm{Ba} 2$ & $\underline{20.3}$ & 2.8 & 0.4 & & & 23.4 \\
\hline Acrobeloides buetschlii & $\mathrm{Ba} 2$ & & 0.4 & & 0.4 & & \\
\hline Acrobeloides nanus & Ba2 & $\underline{43.0}$ & $\underline{40.9}$ & $\underline{30.1}$ & $\underline{30.2}$ & $\underline{45.1}$ & $\underline{38.2}$ \\
\hline Acrobelophis minimus & $\mathrm{Ba} 2$ & $\overline{0.6}$ & & & & $\overline{0.6}$ & \\
\hline Acrolobus emarginatus & $\mathrm{Ba} 2$ & & & 0.1 & 0.1 & & \\
\hline Anaplectus granulosus & $\mathrm{Ba} 2$ & 2.5 & 5.1 & 2.7 & 2.4 & 1.9 & 7.2 \\
\hline Cervidellus cervus & $\mathrm{Ba} 2$ & 0.1 & & & & 0.1 & \\
\hline Cervidellus vexiliger & $\mathrm{Ba} 2$ & 5.8 & 2.7 & & & 0.6 & 8.4 \\
\hline Cephalobus persegnis & $\mathrm{Ba} 2$ & $\underline{17.7}$ & 14.3 & 22.7 & $\underline{24.4}$ & $\underline{27.6}$ & 11.5 \\
\hline Ereptonema arcticum & $\mathrm{Ba} 2$ & $\overline{1.9}$ & & & & & 1.9 \\
\hline Eucephalobus mucronatus & $\mathrm{Ba} 2$ & & 2.9 & & 1.3 & & 1.6 \\
\hline Eucephalobus oxyuroides & $\mathrm{Ba} 2$ & 12.6 & 13.5 & 17.5 & $\underline{22.1}$ & 7.7 & 13.9 \\
\hline Eucephalobus striatus & $\mathrm{Ba} 2$ & 7.2 & 3.3 & $\underline{44.8}$ & 13.5 & 5.1 & $\underline{39.4}$ \\
\hline Eumonhystera dispar & $\mathrm{Ba} 2$ & 1.0 & & & & & 1.0 \\
\hline Eumonystera filiformis & $\mathrm{Ba} 2$ & 1.7 & & & & 2.4 & \\
\hline Geomonhystera villosa & $\mathrm{Ba} 2$ & 1.0 & & & 1.0 & & \\
\hline Heterocephalobus elongatus & $\mathrm{Ba} 2$ & 8.6 & 4.0 & 9.7 & 10.2 & 9.9 & 2.2 \\
\hline Heterocephalobus eurystoma (N) & $\mathrm{Ba} 2$ & & 0.7 & & & & 0.7 \\
\hline Chiloplacus demani & $\mathrm{Ba} 2$ & 7.4 & & & 5.8 & & 1.6 \\
\hline Chiloplacus propinquus & $\mathrm{Ba} 2$ & $\underline{18.2}$ & $\underline{22.6}$ & 23.8 & $\underline{21.6}$ & 12.2 & $\underline{30.8}$ \\
\hline Chiloplacus symmetricus & $\mathrm{Ba} 2$ & & 1.0 & & & 1.0 & \\
\hline Plectus acuminatus & $\mathrm{Ba} 2$ & 1.1 & & 8.1 & 0.9 & 5.6 & 2.6 \\
\hline Plectus cirratus & $\mathrm{Ba} 2$ & 7.3 & 3.1 & & 3.9 & 4.3 & 2.1 \\
\hline Plectus communis & $\mathrm{Ba} 2$ & 3.1 & & & 3.1 & & \\
\hline Plectus longicaudatus & Ba2 & 3.8 & & & & 2.0 & 1.8 \\
\hline Plectus parietinus & Ba2 & 6.3 & 9.9 & 7.6 & 7.0 & 4.4 & 12.4 \\
\hline Plectus parvus & $\mathrm{Ba} 2$ & 10.9 & 15.0 & & 15.5 & 4.6 & 5.8 \\
\hline Plectus rhizophilus & $\mathrm{Ba} 2$ & 0.9 & & & & 0.9 & \\
\hline Plectus silvaticus & $\mathrm{Ba} 2$ & 1.3 & & & & & 1.3 \\
\hline Seleborca complexa & $\mathrm{Ba} 2$ & & 0.7 & & & & 0.7 \\
\hline Stegelletina leopolitensis (N) & $\mathrm{Ba} 2$ & & 0.1 & 3.2 & 0.9 & & 2.4 \\
\hline Wilsonema schuurmansstekhoveni & $\mathrm{Ba} 2$ & 6.5 & 1.7 & & 1.8 & 3.6 & 2.9 \\
\hline Aulolaimus oxycephalus & Ba3 & & 1.1 & & & & 1.1 \\
\hline Bastiania gracilis & Ba3 & & 0.2 & & & & \\
\hline Prismatolaimus intermedius & Ba3 & 2.3 & 1.2 & & & & 3.5 \\
\hline Teratocephalus lirellus & Ba3 & 0.1 & & & & & 0.1 \\
\hline Teratocephalus terrestris & Ba3 & 0.7 & & & & 0.2 & 0.5 \\
\hline Alaimus parvus & $\mathrm{Ba} 4$ & 0.6 & & & 0.6 & & \\
\hline Alaimus primitivus & $\mathrm{Ba} 4$ & 2.2 & 3.7 & 1.3 & 0.4 & 0.5 & 6.3 \\
\hline Amphidelus coronatus & $\mathrm{Ba} 4$ & & & 0.2 & & & 0.2 \\
\hline Amphidelus elegans & $\mathrm{Ba} 4$ & 0.2 & 0.1 & & & 0.2 & 0.1 \\
\hline Tripyla affinis & Ca3 & 0.6 & 0.8 & & & & 1.4 \\
\hline Trischistoma monohystera & Ca3 & & 0.3 & & & 0.3 & \\
\hline Clarkus papillatus & $\mathrm{Ca} 4$ & 2.6 & 1.8 & 0.8 & & 2.3 & 3.0 \\
\hline Coomansus parvus & $\mathrm{Ca} 4$ & 1.3 & & 0.1 & & 1.3 & 0.1 \\
\hline Coomanus zschokkei & $\mathrm{Ca} 4$ & 0.7 & & & & 0.7 & \\
\hline Ironus macramphis & $\mathrm{Ca} 4$ & 0.4 & & & & 0.4 & \\
\hline
\end{tabular}




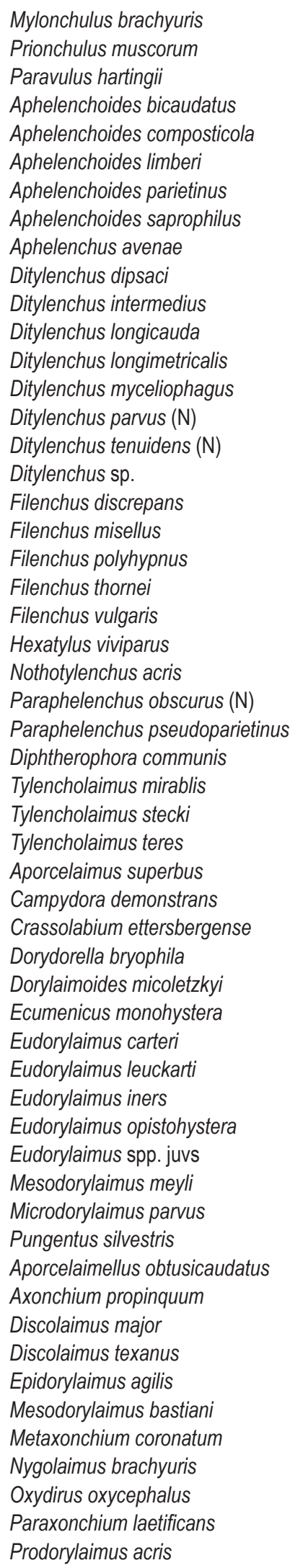

\begin{tabular}{|c|c|c|c|c|c|}
\hline Ca4 & 3.2 & 1.7 & 0.9 & 1.0 & 2.4 \\
\hline $\mathrm{Ca} 4$ & 2.5 & & & & \\
\hline $\mathrm{Ca} 5$ & & & 0.6 & 0.6 & \\
\hline Fu2 & 0.3 & 0.1 & & & 0.1 \\
\hline Fu2 & 9.7 & 11.0 & 0.9 & 7.4 & 5.3 \\
\hline Fu2 & & & 1.4 & 0.2 & \\
\hline Fu2 & 5.5 & 7.4 & 14.8 & 3.2 & 3.0 \\
\hline Fu2 & 1.1 & 1.3 & & 1.0 & 0.1 \\
\hline Fu2 & $\underline{22.8}$ & $\underline{39.5}$ & $\underline{82.4}$ & 21.2 & 35.6 \\
\hline Fu2 & $\overline{0.6}$ & & $\overline{0.5}$ & & \\
\hline Fu2 & 3.6 & & $15.7^{*}$ & 8.3 & 4.7 \\
\hline Fu2 & & 1.1 & & & 0.7 \\
\hline Fu2 & 2.7 & & & & 1.0 \\
\hline Fu2 & 1.7 & 0.7 & & 0.6 & \\
\hline Fu2 & & 1.2 & & 1.2 & \\
\hline Fu2 & 0.8 & & & 0.8 & \\
\hline Fu2 & & 1.7 & & 1.7 & \\
\hline Fu2 & 2.6 & & & & 2.6 \\
\hline Fu2 & 1.0 & & & & 1.0 \\
\hline Fu2 & 7.2 & & & & \\
\hline Fu2 & 3.3 & 2.1 & & 2.1 & 3.3 \\
\hline Fu2 & 8.1 & 19.1 & $\underline{32.2}$ & $\underline{17.6}$ & 13.7 \\
\hline Fu2 & 0.5 & & & & 0.5 \\
\hline Fu2 & & & 0.7 & & \\
\hline Fu2 & & & 4.6 & & \\
\hline Fu2 & 1.5 & 1.8 & 0.8 & & 2.1 \\
\hline Fu3 & 0.3 & 1.4 & & 0.3 & \\
\hline Fu4 & 0.7 & 0.9 & & & \\
\hline Fu4 & 4.3 & 2.8 & & 1.9 & 0.9 \\
\hline Fu4 & 0.3 & & & & \\
\hline Om4 & 0.4 & & & & \\
\hline Om4 & & 0.2 & & & \\
\hline Om4 & 2.4 & 1.0 & & & 1.4 \\
\hline Om4 & 3.7 & 6.7 & & & \\
\hline Om4 & 1.4 & 2.4 & & 1.7 & 1.3 \\
\hline Om4 & 0.2 & 0.4 & 2.4 & & 0.2 \\
\hline Om4 & 3.9 & 19.5 & 9.2 & 10.8 & 10.5 \\
\hline Om4 & 9.9 & 2.3 & 2.5 & 1.5 & 2.7 \\
\hline Om4 & 3.4 & & & & 3.4 \\
\hline Om4 & 2.9 & 2.1 & 1.4 & & 2.3 \\
\hline Om4 & 7.5 & 3.1 & 3.3 & 2.1 & 6.5 \\
\hline Om4 & 2.0 & & & & 2.0 \\
\hline Om4 & 2.8 & 0.2 & 2.4 & & 5.6 \\
\hline Om4 & 0.7 & 3.5 & & & \\
\hline Om5 & 7.8 & 2.2 & 6.8 & 2.3 & 4.7 \\
\hline Om5 & & 0.1 & & 0.1 & \\
\hline Om5 & 0.9 & & & & \\
\hline Om5 & & & 0.5 & & \\
\hline Om5 & 0.4 & & & & 0.4 \\
\hline Om5 & 2.6 & 2.9 & 2.1 & 4.8 & 0.6 \\
\hline Om5 & & 0.6 & & & \\
\hline Om5 & & 1.1 & & & 0.3 \\
\hline Om5 & 2.5 & 2.1 & 1.7 & 0.6 & 2.0 \\
\hline Om5 & 0.6 & 0.1 & 0.5 & & \\
\hline Om5 & 0.6 & 0.4 & & 0.4 & 0.6 \\
\hline
\end{tabular}




\begin{tabular}{|c|c|c|c|c|c|c|c|}
\hline Aglenchus agricola & Pp2 & 1.9 & 6.4 & $\underline{32.9}$ & 10.3 & 4.8 & 28.7 \\
\hline Basiria gracilis & Pp2 & 0.7 & & & & 0.7 & \\
\hline Basiria similis & Pp2 & & 0.6 & & 0.3 & & 0.3 \\
\hline Basiria tumida & Pp2 & 2.0 & & & 1.8 & & 0.2 \\
\hline Boleodorus thylactus & Pp2 & 0.5 & $\underline{24.8}$ & 6.8 & $\underline{21.3}$ & 6.6 & 4.0 \\
\hline Boleodorus volutus (N) & Pp2 & 0.4 & 0.4 & & & & 0.8 \\
\hline Cephalenchus intermedius (N) & Pp2 & & 0.2 & & 0.2 & & \\
\hline Coslenchus andrássyi $(\mathrm{N})$ & Pp2 & & 0.7 & & & 0.7 & \\
\hline Coslenchus costatus & Pp2 & 1.8 & 1.9 & & & & 3.7 \\
\hline Ecphyadophora tenuissima (N) & Pp2 & 0.4 & & & & & 0.4 \\
\hline Malenchus acarayensis & Pp2 & 9.1 & & & 7.6 & 4.4 & \\
\hline Malenchus bryophilus & Pp2 & 12.4 & 2.2 & & & 14.6 & \\
\hline Malenchus exiguus & Pp2 & 2.6 & 10.1 & 2.7 & & 1.0 & 6.8 \\
\hline Malenchus gratiosus & Pp2 & 0.9 & & & & & 0.9 \\
\hline Neopsilenchus magnidens & Pp2 & & 0.5 & & 0.5 & & \\
\hline Tylenchus davainei & Pp2 & 4.6 & 5.4 & 1.6 & 2.7 & 2.9 & 5.9 \\
\hline Paratylenchus bukowinensis & Pp2 & & & 15.8 & & 11.5 & 4.3 \\
\hline Paratylenchus microdorus & Pp2 & & 10.9 & & 3.5 & 6.4 & 1.0 \\
\hline Paratylenchus projectus & Pp2 & 3.4 & & & & 3.4 & \\
\hline Psilenchus hilarulus & Pp2 & & 2.0 & 0.9 & & 2.6 & 0.2 \\
\hline Amplimerlinius macrurus & Pp3 & 0.7 & 14.8 & & 14.3 & & 0.7 \\
\hline Bitylenchus dubius & Pp3 & & 10.8 & 12.8 & 4.1 & 19.5 & \\
\hline Bitylenchus maximus & Pp3 & & 2.2 & & & 1.7 & 0.5 \\
\hline Geocenamus brevidens & Pp3 & 7.1 & 5.2 & & 6.5 & & 1.7 \\
\hline Geocenamus microdorus & Pp3 & & $\underline{21.0}$ & & & & $\underline{21.0}$ \\
\hline Geocenamus nanus & Po3 & & & 8.8 & & 8.8 & 5.0 \\
\hline Helicotylenchus canadensis & Pp3 & 3.8 & 1.3 & & & 5.1 & \\
\hline Helicotylenhus digonicus & Pp3 & 11.0 & 0.6 & & & 3.3 & 8.4 \\
\hline Helicotylencus dihystera & Pp3 & & & 10.2 & & & 10.2 \\
\hline Heterodera mani juvs & Pp3 & & 1.2 & & 1.2 & & \\
\hline Heterodera avenae juvs & Pp3 & & 0.3 & 0.6 & & 0.9 & \\
\hline Meloidogyne hapla & Pp3 & & 1.1 & & & 1.1 & \\
\hline Nagelus obscurus & Pp3 & & 1.1 & & & & 1.1 \\
\hline Pratylenchoides crenicauda & Pp3 & 0.8 & 0.5 & & & & 1.3 \\
\hline Pratylenchus crenatus & Pp3 & & & 1.3 & & 0.7 & 0.6 \\
\hline Pratylenchus penetrans & Pp3 & 4.6 & & 9.7 & & 7.5 & 9.7 \\
\hline Pratylenchus pratensis & Pp3 & & 9.1 & 7.4 & 6.3 & 0.6 & 6.8 \\
\hline Tylenchorhynchus bicaudatus & Pp3 & 0.1 & & & & & 0.1 \\
\hline Tylenchorhynchus cylindricus & Pp3 & & & 2.3 & & & 2.3 \\
\hline Longidorus elongatus & Pp5 & & 0.3 & & 0.3 & & \\
\hline Longidorus intermedius & Pp5 & 0.5 & & & & & 0.5 \\
\hline Total number of species & & 99 & 90 & 53 & 60 & 81 & 102 \\
\hline
\end{tabular}

juvs, juveniles; (N), species new for Slovak fauna

es, such as bulldozing, slash-and-burn management, windstorms, and wildfires in forests, however, can substantially reduce nematode diversity (Yeates, 2007; Čerevková et al., 2013). The species richness of the nematode fauna in FOR in our study was higher than in the soils of a protected forest in the Slovak Tatra National Park nine years after a windstorm and wildfire, likely due to the persistent influence of changes in the plant community and basal soil physicochemical properties (Renčo \& Čerevková, 2015; Renčo et al., 2015).
The FOR soils also had the highest microbial biomass, richness, and diversity, what positively correlated with $\mathrm{C}$ and $\mathrm{N}$ contents, and was consistent with the observations of Yergeau et al., (2006)). Microbial biomass is involved in the control of the synthesis and decomposition of soil organic matter and acts as an accessible storage system for nutrients in ecosystems. Sites with high microbial biomass can therefore stock and recycle more nutrients for plant nutrition and thus improve the sustainability of an ecosystem (Kaschuk et al., 2010). In contrast, the number and diversity 
of nematode species and diversity of microbial functional groups in our study were lowest in AGR. Additionally, AGR had half the amount of microbial biomass than FOR and MEA, and microbial biomass was negatively correlated with $\mathrm{C}$ and $\mathrm{N}$ contents. These findings support our hypothesis that biological diversity would be lowest in the agricultural soils due to periodic perturbation, land management, and crop monoculturing, consistent with the results by Neher et al., (2005); even though AGR had the highest overall nematode abundance, likely due the periodic organic manure inputs (Hu et al., 2018).

Bacterivorous nematodes are often the most dominant feeding group in forest (Neher et al., 2005; Yeates, 2007; Renčo \& Čerevková, 2017) and agricultural (Neher et al., 2005, Renčo et al., 2010) soils. The preponderance of $\mathrm{Ba}_{2}$ bacterivores ( $A$. nanus, C. persegnis, and $C$. propinquus) in all ecosystems in our study was likely due to the high microbial biomasses in FOR and MEA and to the management (tillage and fertilisation) in the corn monoculture in AGR. Microbial biomass was nevertheless significantly lower in AGR than FOR and MEA. Microbial diversity is often lower after a natural habitat has been cultivated (Buckley \& Schmidt, 2001). These results are in agreement with Wasilewska (1997), who stated that a higher abundance of microflora would support larger numbers of bacterivorous nematodes. An increase in the abundance of this group is indicative of enhanced microbiological activity e.g. after the addition of cow and chicken manure or slurry (Wasilewska, 1997; Neher \& Olson, 1999). Our study thus demonstrated the synchronisation between bacterivorous nematodes and their food resources, which has not been frequently reported (Wardle et al., 2001, Papatheodorou et al., 2004). Fungivorous nematodes $\left(\mathrm{Fu}_{2}\right)$ were the second most abundant trophic group in all ecosystems. AGR had the highest abundance of fungivores, mainly $A$. avenae, F. vulgaris, Ditylenchus intermedius, and Aphelenchoides parietinus, likely due to the high density of fungal hyphae and spores under $Z$. mays monoculture from the association of corn with arbuscular mycorrhizal fungi (Bai et al., 2008).

Plants and their root systems serve as food for plant parasitic nematodes (Flis et al., 2018; Le et al., 2019) before they serve as a food source for microbivorous nematodes during decomposition. Root systems are more diverse in natural ecosystems with rich communities of plant species than for monocultured crops. Root growth is also more extensive and less ephemeral in perennial plants than annual crops and supports a soil community with many species of plant parasites, omnivores, and predators (Neher, 2010). Plant parasites are common in natural grasslands (Popovici \& Ciobanu, 2000; Čerevková, 2006). The abundance of plant parasites, such as Boleodorus thylactus, Malenchus exiguus, and Paratylenchus microdorus $\left(\mathrm{Pp}_{2}\right)$ or Amplimerlinius macrurus, $\mathrm{Ge}$ ocenamus microdorus, and Bitylenchus dubius $\left(\mathrm{Pp}_{3}\right)$ was highest in MEA.

The importance and high population densities of plant parasitic nematodes in agriculture are mainly associated with specific crop pests, e.g. root-knot and cyst-forming endoparasites (e.g. Meloid- ogyne, Heterodera, and Globodera). The high overall abundance of $\mathrm{Pp}$ nematodes in AGR (Aglenchus agricola $\mathrm{Pp}_{2}$, Paratylenchus bukowinensis $\mathrm{Pp}_{2}$, Bitylenchus dubius $\mathrm{Pp}_{3}$, and Helicotylenchus dihystera $\mathrm{Pp}_{3}$ are all ectoparasites) suggests their close relationship with cultured crops. Omnivores and carnivores were significantly more abundant in MEA and FOR than AGR, consistent with previous findings by Neher et al., (2005) and Renčo et al., (2010).

Relationships of soil type with soil properties and nematode and microbial communities

Soil type was also an important factor affecting the nematode and microbial communities and soil properties. Soil properties were best in $\mathrm{CM}$, with a neutral $\mathrm{pH}$ and the highest $\mathrm{C}$ and $\mathrm{N}$ contents and $\mathrm{C} / \mathrm{N}$ ratio, followed by $\mathrm{CS}$ and $\mathrm{SS}$. $\mathrm{C}$ and $\mathrm{N}$ contents were twice as high in CM than SS, in agreement with the general soil classification (www.vupop.sk).

Soil type was more important than ecosystem type for both the nematode and microbial communities. For example, nematode abundance, number of nematode species, and microbial biomass or diversity positively correlated in the CM soil type in two out of three ecosystems studied. Significant effects of soil type on the composition of nematode communities have been documented by Alphei (1998) and Lišková et al., (2008) in forests, by Popovici and Ciobanu (2000) in grasslands, and by Neher et al., (2005) in agricultural land. The populations of bacterivores (mainly $A$. nanus, Eucephalobus striatus, and $C$. propinquus) and fungivores ( $A$. avenae and $F$. vulgaris) and microbial biomass in our study were highest in $\mathrm{CM}$ with aerobic conditions, a neutral $\mathrm{pH}$, and a high humus content beneficial to microbial activities and associated nematodes (Wasilewska, 1997). In contrast, the abundances of bacterivores and fungivores were low in SS because of its oxygen deficiency and acidic conditions. These results partially agreed with those by Lišková et al., (2008), who reported that Cephalobidae bacterivores (Acrobeloides, Acrobeles and Cervidellus) were more abundant in a light sandy Regosol with a high $\mathrm{pH}$, but disagreed with those by Wasilewska (1997) and Lišková et al., (2008), who reported that fungivores were more abundant in an acidic Cambisol.

The abundance of facultative plant parasites $\left(\mathrm{Pp}_{2}\right)$ did not differ amongst the soil types. A. agricola in CM, Malenchus bryophilus in $\mathrm{CS}$, and $B$. thylactus in SS were nevertheless the most abundant, supporting the preference of various species of $\mathrm{Pp}_{2}$ nematodes for different soil types, also reported by Lišková et al., (2008). In contrast, obligate plant parasites $\left(\mathrm{Pp}_{3}\right)$ were most abundance in CM, followed by CS and SS, probably due to the different levels and distributions of food sources between these soil types, as also suggested by Popovici and Ciobanu (2000) and Lišková et al., (2008). Natural ecosystems are characterised by high proportions of omnivores and predators (Wasilewska, 1997; Ferris et al., 2001). Omnivores and predators were most abundant in CM, but only in FOR and MEA.

In our study soil type was also as important factor affecting values 
of all ecological and functional indices, contradicting findings of Lišková at al., (2008), who reported that only fungal to bacteria $(\mathrm{F} / \mathrm{B})$ ratio and channel index $(\mathrm{Cl})$ was significantly different among Cambisol, Regosol, Fluvisol and Rendzina soil types. Ruess (2003) studied $\mathrm{Cl}$ and F/B at various sites and stated that soil and climate affect $\mathrm{Cl}$ more strongly than does ecosystem type. In our study $\mathrm{Cl}$ was significantly affected by both, ecosystem and soil type as well as their interactions, and sampling date has no impact on $\mathrm{Cl}$ values.

In general, season (sampling date) in our study had relatively minor effects on both the abiotic and biotic characteristics. Only SM content fluctuated with the season (lowest in summer) what significantly affecting microbial biomass, confirming results of Buchanan and King (1992). Similar overall nematode abundance influences sampling date, which can partly be explained by changes in SM, in agreement with observation of Sohlenius and Boström (2001) from Swedish Scot pine forest soils. Out of functional guilds, $\mathrm{Ba}_{2}, \mathrm{Fu}_{2}$, and $\mathrm{Pp}_{2}$ nematodes were influenced by sampling date, however only $\mathrm{Ba}_{2}$ were negatively correlated with SM content.

\section{Conclusion}

The differences in soil properties, nematode communities, and microbial biomasses amongst the soil and ecosystem types suggest an obvious impact of environmental variables on biotic and abiotic soil characteristics. The differences were larger amongst the soil types than the ecosystems. CM had the best soil properties, with a neutral $\mathrm{pH}$ and the highest $\mathrm{C}$ and $\mathrm{N}$ contents and $\mathrm{C} / \mathrm{N}$ ratio and thus the highest number of species and diversity of nematode communities, as well as the MI, $\Sigma \mathrm{MI}, \mathrm{PPI}, \mathrm{SI}$, and TD nematode ecological indices, and microbial biomass, richness, and diversity. The majority of the abiotic and biotic characteristics varied the most between CM and SS. The abiotic and biotic soil properties and their interactions were best in FOR, where the number of species and diversity of nematode communities, as well as the MI, $\Sigma \mathrm{MI}, \mathrm{PPI}, \mathrm{SI}$, and TD ecological indices, and microbial biomass, richness, and diversity were highest. SM, C, and N contents and the $\mathrm{C} / \mathrm{N}$ ratio were also highest in $\mathrm{FOR}$, but the $\mathrm{pH}$ was lowest. $\mathrm{C}$ and $\mathrm{N}$ contents were twice as high in FOR than AGR but were similar to those in MEA, suggesting that established forests and natural meadows represent relatively stable environments, providing suitable conditions for soil microbial and nematode communities. $\mathrm{C} / \mathrm{N}$ ratios and biological diversity were lower in the cultivated soils than in the natural ecosystems soils, likely due to periodic perturbation. This resulted in a lower abundance and diversity of nematode communities and microbial diversity. FOR and AGR generally differed the most. The soil properties, nematode communities, and microbial biomass were more similar in FOR and MEA. A multivariate analysis indicated that the abundance of most of the nematode guilds, total nematode abundance, number of nematode species, and microbial characteristics tended to be higher in the environment with a higher $\mathrm{pH}$, the $\mathrm{N}$ and $\mathrm{C}$ contents. Sampling dates had a minor or no effect on most of the parameters, except the SM content, abundance of c-p2 nematodes, microbial richness, and several of the nematode ecological indices.

\section{Conflict of Interest}

Authors have no potential conflict of interest pertaining to this submission to Helminthologia.

\section{Acknowledgement}

The authors acknowledge the support of the Slovak research and development agency, Project number APVV 15-0176

\section{References}

ALPHEI. J. (1998): Differences in soil nematode community structure of beech forests: comparison between a mull and a moder soil. Appl. Soil Ecol., $9(1-3)$ : 9 - 15. DOI: 10.1016/S09291393(98)00047-X

BAI, J., LIN, X., YINM, R. (2008): The influence of arbuscular mycorrhizal fungi on $A s$ and $P$ uptake by maize Zea mays $L$. from As-contaminated soils. Appl. Soil Ecol., 38(2): 137 - 145. DOI: 10.1016/j.apsoil.2007.10.002

BriaR, S.S., Grewal, P.S., SomaseKhar, N. (2007): Soil nematode community, organic matter, microbial biomass and nitrogen dynamics in field plots transitioning from conventional to organic management. Appl. Soil Ecol., 37(3): 256 - 266. DOI: 10.1016/j. apsoil.2007.08.004

Bhusal, D.R., Kallimanis, A.S., Tsiafouli, M.A., Sgardelis, S.P. (2014): Higher taxa vs. functional guilds vs. trophic groups as indicators of soil nematode diversity and community structure. Ecol. Indic., 41: 25 - 29. DOI: 10.1016/j.ecolind.2014.01.019

Bloem, J., de Ruiter, P.C., Koopman, G.J., LebBink, G., Brussaard, L. (1992). Microbial numbers and activity in dried and rewetted arable soil under integrated and conventional management. Soil Biol. Biochem., 24(7): 655 - 665. DOI: 10.1016/0038-0717(92)90044-X Bobu'ská, L., Fazekašová, D., Angelovičová L. (2015): Vertical profiles of soil properties and microbial activities in peatbog soils in Slovakia. Environmental Process 2(1): 411-418. DOI: 10.1007/s40710-015-0073-7

BlagodatskII, S. A., Bogomolova, I. N., Blagodatskaya, E. V. (2008). Microbial biomass and growth kinetics of microorganisms in chernozem soils under different land use modes. Microbiology, 77(1): 99 - 106. DOI: 10.1134/S0026261708010141

Bongers T. (1990): The maturity index: an ecological measure of environmental disturbance based on nematode species composition. Oecologia 83(1): 14 - 19. DOI: 10.1007/BF00324627

BONGERS, T., Bongers, M. (1998): Functional diversity of nematodes. Appl. Soil Ecol., 10(3): 239 - 251. DOI: 10.1016/S09291393(98)00123-1

BuckLEY, D.H., SchmidT, T.M. (2001): The structure of microbial 
communities in soil and the lasting impact of cultivation. Microb. Ecol., 42(1): 11 - 21. DOI: 10.1007/s002480000108

Buchanan, M., KING, L.D. (1992). Seasonal fluctuations in soil microbial biomass carbon, phosphorus, and activity in no-till and reduced-chemical-input maize agroecosystems. Biol. Fertil. Soils 13(4): 211 - 217. DOI: 10.1007/BF00340578

Cesarz, S., Ruess, L., Jacob, M., Jacob, A., Schaefer, M., Scheu, S. (2013). Tree species diversity versus tree species identity: driving forces in structuring forest food webs as indicated by soil nematodes. Soil Biol. Biochem., 62: 36 - 45. DOI: 10.1016/j.soilbio. 2013.02.020

Compton, J.E, Boone, R.D. (2000): Long-term impacts of agriculture on soil carbon and nitrogen in New England forests. Ecology, 81(8): 2314 - 2330. DOI: 10.1890/0012-9658(2000)081

CoBB, N.A. (1918): Estimating the nematode population of the soil. Agric Tech Circ Bur PI Ind US Dep Agric No.1, 150 pp

Čerevková, A (2006): Nematode communities in three types of grassland in the Slovak Republic. Helminthologia 43(3): 171 176. DOI: 10.2478/s11687-006-0032-y

Čerevková, A., Renčo, M., Cagáñ, L. (2013): Short-term effects of forest disturbances on soil nematode communities in European mountain spruce forests. J. Helminth., 87(3): 376 - 385. DOI: 10.1017/S0022149X12000508

Degens, B.P., HaRrIS, J.A. (1997): Development of a physiological approach to measuring the catabolic diversity of soil microbial communities. Soil Biol. Biochem., 29(9 - 10): 1309 - 1320. DOI: 10.1016/S0038-0717(97)00076-X

Dıck, R.P. (1992): A review: long-term effects of agricultural systems on soil biochemical and microbial parameters. Agric. Ecos. Envir., 40(1 - 4): 25 - 36. DOI: 10.1016/0167-8809(92)90081-L

Domsch, K.H., Jagnow, G., Anderson, T.H. (1983): An ecological concept for the assessment of side-effects of agrochemicals on soil microorganisms. In: Gunther, F.A. (Ed) Residue Reviews. Springer, New York, NY, pp. 65 - 130

Ekschmitt, K., Bakonyl, G., Bongers, M., Bongers, T., Boström, S., Dogan, H., Sohlenius, B. (2001): Nematode community structure as indicator of soil functioning in European grassland soils. Eur. $J$ Soil Biol. 37(4): 263 - 268. DOI: 10.1016/S1164-5563(01)01095-0 FAng, X., Yu, D., Zhou, W., Zhou, L., DAl, L. (2016). The effects of forest type on soil microbial activity in Changbai Mountain, Northeast China. Annals For. Sci., 73(2), 473 - 482. DOl: 10.1007/ s13595-016-0540-y

Fernandes, E.C.M., Motavalli, P.P., Castilla, C., Mukurumbira, L. (1997): Management control of soil organic matter dynamics in tropical land-use systems. Geoderma, 79(1 - 4): 49 - 67. DOI: 10.1016/S0016-7061(97)00038-4

Ferris, H., Bongers, T., De Goede, R.G.M. (2001): A framework for soil food web diagnostics: extension of the nematode faunal analysis concept. Appl. Soil Ecol., 18(1): 13 - 29. DOI: 10.1016/ S0929-1393(01)00152-4

Flis, L., Dobosz, R., Rybarczyk-Mydlowska, K., Wasilewska-Nasclemento, B., Kubicz, M., WiniszewsKa, G. (2018): First report of the lesion nematodes: Pratylenchus brachyurus and Pratylenchus delattrei on tomato (Solanum lycopersicum L.) plants in Cape Verde. Helminthologia, 55(1): 88 - 94. DOI: 10.1515/helm-2017-0053

FuHRMAN, J.A. (2009): Microbial community structure and its functional implications. Nature, 459:193 - 199

Garland, J.L., Mills, A.L. (1991): Classification and characterization of heterotrophic microbial communities on the basis of patterns of community-level sole-carbon-source utilization. Appl. Environ. Microb., 57(8): 2351 - 2359

Garbach, K., Milder, J.C., DeClerck, F.A., Montenegro, de Wit M., Driscoll, L., Gemmill-Herren, B. (2017): Examining multi-functionality for crop yield and ecosystem services in five systems of agroecological intensification. Int. J. Agric. Sustain., 15(1): 11 - 28. DOI: 10.1080/14735903.2016.1174810

Gaugler, R., BILgrami, A. (2004): Nematode Behaviour. CABI Publishing, Oxfordshire and Cambridge, $419 \mathrm{pp}$

Gömöryová, E., Střelcová, K., Fleischer, P., Gömöry, D. (2011): Soil microbial characteristics at the monitoring plots on windthrow areas of the Tatra National Park Slovakia: their assessment as environmental indicators. Environ. Monitor. Assess., 174(1 - 4): 31 - 45. DOI: 10.1007/s10661-010-1755-2

HÁnĚL, L. (2017): Soil nematodes in alpine meadows of the Tatra National Park (Slovak Republic). Helminthologia, 54(1): 48 - 67. DOI: 10.1515/helm-2017-0005

Heip, C., Herman, P.M.J., Soetaert, K. (1988): Data processing evaluation and analysis. In: HIGgINS, H.P., THIEL, H. (Eds) Introduction to the study of meiofauna. Smithsonian Institution Press, Washington, pp. $25-30$

Högberg, M.N., Högberg, P., Myrold, D.D. (2007): Is microbial community composition in boreal forest soils determined by $\mathrm{pH}$, C-to-N ratio, the trees, or all three? Oecologia, 150(4): 590 - 601. DOI: 10.1007/s00442-006-0562-5

Hu, C., XIA, X.G., Han, X.M., Chen, Y.F., QIAO, Y., LIU, D. H., LI, S. $\mathrm{L}$. (2018): Soil nematode abundances were increased by an incremental nutrient input in a paddy-upland rotation system. Helminthologia, 55(4): 322 - 333. DOI: 10.2478/helm-2018-0025

INSAM, H. (1997): A new set of substrates proposed for community characterization in environmental samples. In: INSAM, H., RANGGER, A. (Eds) Microbial Communities. Functional versus Structural Approaches. Springer, Heidleberg. pp. 260 - 261

ISLAM, K.R, WEIL, R.R. (1998): Microwave irradiation of soil for routine measurements of microbial biomass carbon. Biol. Fertil. Soils, 27(4): 408 - 416. DOI: 10.1007/s003740050

Jangid, K., Williams, M.A., Franzluebbers, A.J., Schmidt, T.M., ColeMAN, D.C., WhitMAn, W.B. (2011): Land-use history has a stronger impact on soil microbial community composition than aboveground vegetation and soil properties. Soil Biol. Biochem., 43(1): 2184 2193. DOI: $10.1016 /$ j.soilbio.2011.06.022

Kaur, A., Chaudhary, A., Kaur, A., Choudhary, R., Kaushik, R. (2005): Phospholipid fatty acid-a bioindicator of environment monitoring and assessment in soil ecosystem. Curr. Sci. 89:1103 $-1112$ 
KaUtz, T., WiRTh, S., ElLmer, F. (2004). Microbial activity in a sandy arable soil is governed by the fertilization regime. Eur. J Soil Biol., 40(2), 87 - 94. DOI: 10.1016/j.ejsobi.2004.10.001

KaschuK, K., Alberton, O., Hungria, M. (2010): Three decades of soil microbial biomass studies in Brazilian ecosystems: lessons learned about soil quality and indications for improving sustainability. Soil Biol. Biochem., 42(1): 1 - 13. DOI: 10.1016/j.soilbio.2009.08.02

Lange, M., Eisenhauer, N., Sierra, C.A., Bessler, H., Engels, C., GRIFFITHS, R.I., SteInBEISS, S. (2015). Plant diversity increases soil microbial activity and soil carbon storage. Nature Comm., 6(1), 1 8. DOI: 10.1038/ncomms 7707

Lima da Silva, J.V.C., HiRschfeld, M.N.C., Cares, J.E., Esteves, A.M. (2019). Land use, soil properties and climate variables influence the nematode communities in the Caatinga dry forest. Appl. Soil Ecol., 103474. DOI: 10.1016/j.apsoil.2019.103474

LIŠKovÁ, M., Čerevková, A., HÁnĚL, L. (2008): Nematode communities of forest ecosystems in association with various soil orders. Russ. J. Nematol. 16(2): $129-142$

Losos, B., GuLIČKA, J., LELLÁK, J., PELIKÁN, J. (1984): Animal Ecology. Státní pedagogické nakladatelství Praha, In Czech, 120 pp.

Mangalassery, S., Mooney, S.J., Sparkes, D. L., Fraser, W.T., SJÖGERSTEN, S. (2015). Impacts of zero tillage on soil enzyme activities, microbial characteristics and organic matter functional chemistry in temperate soils. Eur. J Soil Biol., 68:9 - 17. DOI: 10.1016/j. ejsobi.2015.03.001

Martin-Laurent, F., Philippot, L., Hallet, S., Chaussod, R., Germon, J.C., Soulas, G., Catroux, G. (2001): DNA extraction from soils: old bias for new microbial diversity analysis methods. Appl. Environ. Microb., 67(5): 2354 - 2359. DOI: 10.1128/AEM.67.5.23542359.2001

Murty, D., Kirschbaum, M.U., McMurtrie, R.E., McGilvray, H. (2002): Does conversion of forest to agricultural land change soil carbon and nitrogen? A review of the literature. Global Change Biol., 8(2): 105 - 123. DOI: 10.1046/j.1354-1013.2001.00459.x Nannipieri, P., Ascher, J., Ceccherinl, M.T., Landi, L., Pietramellara, G., RenelLA, G. (2003): Microbial diversity and soil functions. Eur. J. Soil Sci., 54(4): 655 - 670. DOI: 10.1046/j.1351-0754.2003.0556.x NehER, D. A. (2001). Role of nematodes in soil health and their use as indicators. J. Nematol., 33(4), 161.

Neher, D.A. (2010): Ecology of plant and free-living nematodes in natural and agricultural soil. Ann. Rev. Phytopath., 48(4): 371 394. DOI: 10.1146/annurev-phyto-073009-114439

Neher, D.A., Olson, R.K. (1999): Nematode communities in soils of four farm cropping management systems. Pedobiologia, 43(5): $430-438$

Neher, D.A, Wu, J., Barbercheck, M.E., Anas, O. (2005): Ecosystem type affects interpretation of soil nematode community measures. Appl. Soil Ecol., 30(1): 47 - 64. DOI: 10.1016/j.apsoil.2005.01.002

Nielsen, U.N, Ayres, E., Wall, D.H., Li, G., Bardgett, R.D., Wu, T., GAREY, J.R. (2014): Global-scale patterns of assemblage structure of soil nematodes in relation to climate and ecosystem properties. Global Ecol. Biogeog., 23(9): 968 - 978. DOI: 10.1111/ geb.12177

Le, T. M. L., Nguyen, T. D., Nguyen, H. T., Liebanas, G., Nguyen, T. A. D., TRINH, Q. P. (2019). A new root-knot nematode, Meloidogyne moensi n. sp.(Nematoda: Meloidogynidae), parasitizing Robusta coffee from Western Highlands, Vietnam. Helminthologia, 56(3): 229 - 246. DOI:10.2478/helm-2019-0017

OlemBo, R., HaWkSWORTH, D.L. (1991): Importance of microorganisms and invertebrates as components of biodiversity. Biodiversity of microorganisms and invertebrates: its role in sustainable agriculture. In Proceedings of the First Workshop on the Ecological Foundations of Sustainable Agriculture WEFSA 1. London, UK, CAB International

Papatheodorou, E.M, Argyropoulou, M.D., Stamou, G.P. (2004): The effects of large-and small-scale differences in soil temperature and moisture on bacterial functional diversity and the community of bacterivorous nematodes. Appl. Soil Ecol., 25(1): $37-49$. DOI: 10.1016/S0929-1393(03)00100-8

Popovici, I., CIOBANu, M. (2000): Diversity and distribution of nematode communities in grasslands from Romania in relation to vegetation and soil characteristics. Appl. Soil Ecol., 14: 27 - 36

RenČO, M., BaležENTIENÉ, L. (2015): An analysis of soil free-living and plant-parasitic nematode communities in three habitats invaded by Heracleum sosnowskyi in central Lithuania. Biol. Inv., 17(4): 1025 - 1039. DOI: 10.1007/s10530-014-0773-3

ReNČO, M., ČEREVKOVÁ, A. (2015): Long-term effects of a wildfire on the soil nematode communities in the spruce forest ecosystem of High Tatra National Park. Int. J. Wild. Fire, 24(5): 702 - 711. DOI: 10.1071/WF14138

Renčo, M., Čerevková, A. (2017): Windstorms as mediator of soil nematode community changes: Evidence from European spruce forest. Helminthologia, 54(1): 36 - 47. DOI: 10.1515/helm-20170004

Renčo, M., Čerevková, A., Homolová, Z., Gömöryová, E. (2015): Long-term effects on soil nematode community structure in spruce forests of removing or not removing fallen trees after a windstorm. For. Ecol. Manag., 356(3): 243 - 252. DOI: 10.1016/j.foreC0.2015.07.008

Renčo, M., Čermák, V., Čerevková, A. (2012): Composition of soil nematode communities in native birch forests in Central Europe.Nematology, 14(1):15-25.DOI:10.1163/138855411X575430 RENČO, M., LIŠKOVÁ, M., ČEREVKOVÁ, A. (2010): Seasonal fluctuations of the nematode communities in a hop garden soil. Helminthologia, 47(2): 115 - 122. DOI: 10.2478/s11687-010-0018-7

RUESS, L. (2003): Nematode soil faunal analysis of decomposition pathways in different ecosystems. Nematology, 5(2): 179 - 181. DOI: 10.1163/156854103767139662

Sánchez-Moreno, S., Cano, M., López-Pérez, A., Benayas, J.M.R (2018): Microfaunal soil food webs in Mediterranean semi-arid agroecosystems. Does organic management improve soil health? Appl. Soil Ecol., 125: 138 - 147. DOI: 10.1016/j.apsoil.2017.12.020 
Schutter, M., Sandeno, J., Dick, R. (2001): Seasonal, soil type, and alternative management influences on microbial communities of vegetable cropping systems. Biol. Fertil. Soils, 34(6): $397-410$. DOI: 10.1007/s00374-001-0423-7

SEINHORST, J.W. (1962): On the killing, fixation and transferring to glycerine of nematodes. Nematologica, 8(1): $29-32$

Shannon, C.E., Weaver, W. (1949): The mathematical theory of communication. University of Illinois Press, Urbana

SMLL, V. (1999): Crop residues: agriculture's largest harvest: Crop residues incorporate more than half of the world's agricultural phytomass. BioScience, 49(2): 299 - 308. DOI: 10.2307/1313613

SohlenIUS, B., Boström, S. (2001): Annual and long-term fluctuations of the nematode fauna in a Swedish Scots pine forest soil. Pedobiologia, 45(5): 408 - 429. DOI: 10.1078/0031-405600096

ŠÁY, M. (1985): Production of free living nematodes in the Protected landscape area of the Slovak Paradise. Ekológia ČSSR, 4(1): $185-209$

Ter BraAk, C.J.F, Šmilauer, P. (2012) Canoco reference manual and user's guide: Software for ordination. Version 5. Microcomputer Power, Ithaca, NY. 496 pp

van Benzoljen, J. (2006): Methods and techniques for nematology. The Netherlands, Wagenningen University, $156 \mathrm{pp}$

Whitford, W.G., Pen-Mouratov, S., Steinberger, Y. (2014): The effects of prescribed fire on soil nematodes in an arid juniper savanna. Open J. Ecol., 4(2): 66 - 75. DOI: 10.4236/oje.2014.42009 Wardle, D.A, Yeates, G.W., Bonner, K.L., Nicholson, K.S., Watson, R.N. (2001): Impacts of ground vegetation management strategies in a kiwifruit orchard on the composition and functioning of the soil biota. Soil Biol. Biochem., 33(7 - 8): 893 - 905. DOI: 10.1016/ S0038-0717(00)00235-2

WASILEWSKA, L. (1997): Soil invertebrates as bioindicators with special reference to soil-inhabiting nematodes. Russ. J. Nematol., 5(3): $113-126$

Yergeau, E., BokHoRst, S., HuIskes, A.H. (2006) Size and structure of bacterial, fungal and nematode communities along an Antarctic environmental gradient. FEMS Microbiol. Ecol., 59(3): 436 - 451. DOI: 10.1111/j.1574-6941.2006.00200.x

YEATES, G.W. (1994): Modification and qualification of the Nematode Maturity Index. Pedobiologia, 38(1): 97 - 101

YEATES, G.W. (2003): Nematodes as soil indicators: functional and biodiversity aspects. Biol. Fertil. Soils., 37(2): 199 - 210. DOI: 10.1007/s00374-003-0586-5

YEATES, G.W. (2007): Abundance, diversity, and resilience of nematode assemblages in forest soils. Can. J. For. Res., 37(1): 216 -225. DOI: $10.1139 / \times 06-172$

YounG, I.M, RITZ, K. (1998): Can there be a contemporary ecological dimension to soil biology without a habitat? Soil Biol. Biochem., 30(4): $1229-1232$

Zakarauskaitė, D., Vaišvila, Z., Motuzas, A., Grigaliūniené, K., BuivYDAITE, V.V., VaISVALAVIČIUS, R., ButKus, V. (2008). The influence of long-term application of mineral fertilizers on the biological activity of Cambisols. Ekologija, 54(3): 173 - 178

Zhang, Y., Cong, J., Lu, H., Yang, C., Yang, Y., Zhou, J., LI, D. (2014). An integrated study to analyze soil microbial community structure and metabolic potential in two forest types. PloS ONE, 9(4). DOI: 10.1371/journal.pone.0093773 